\title{
PEMELIHARAAN IKAN NILA (Oreochromis niloticus) DENGAN SISTEM AKUAPONIK DI DESA KARANG ENDAH, KECAMATAN GELUMBANG, KABUPATEN MUARA ENIM SUMATRA SELATAN
}

\section{Culturing of Nile Tilapia (Oreochromis niloticus) with Aquaponic System in Karang Endah Village, Gelumbang District, Muara Enim Regency South Sumatera}

\author{
Marini Wijayanti ${ }^{1 *}$, Husnul Khotimah ${ }^{1}$, Ade Dwi Sasanti ${ }^{1}$, Sefti Heza Dwinanti ${ }^{1}$ dan Madyasta Anggana \\ Rarassari ${ }^{1}$ \\ ${ }^{1}$ Program Studi Budidaya Perairan, Fakultas Pertanian, Universitas Sriwijaya, Indralaya \\ *mariniwijayanti@fp.unsri.ac.id
}

\begin{abstract}
Abstrak
Akuaponik adalah gabungan budidaya ikan dan tanaman hidroponik dengan sistem resirkulasi. Akuaponik merupakan salah satu alternatif yang dapat memanfaatkan limbah budidaya ikan serta mampu menghemat penggunaan lahan dan air. Tujuan dari kegiatan ini adalah memberikan informasi kepada para pembudidaya mengenai pemeliharaan ikan nila dan tanaman kangkung dengan sistem akuaponik. Kegiatan ini dilaksanakan pada bulan September sampai November 2018. Pemeliharaan ikan nila dengan sistem akuaponik dilakukan selama 37 hari, dikolam beton ukuran $3 \times 1,5 \times 1 \mathrm{~m}^{3}$, dengan jumlah ikan yang ditebar 200 ekor. Hasil pemeliharaaan didapatkan pertumbuhan ikan nila sebesar 3,31 $\pm 0,68 \mathrm{~cm}$ dan $21,59 \pm 4,28 \mathrm{~g}$. Laju pertumbuhan spesifik ikan nila sebesar 2,07\%.hari ${ }^{-1}$ dengan tingkat kelangsungan hidup sebesar 95\%. Tanaman kangkung mengalami pertumbuhan sebesar $47,86 \pm 2,81 \mathrm{~cm}$ dan $16,85 \pm 2,74 \mathrm{~g}$.
\end{abstract}

Kata kunci: Ikan Nila, Tanaman kangkung, Akuaponik

\section{Abstract}

Aquaponic is an aquaculture system which combines fish and hydroponic plants in a recirculating order. Aquaponic is one of the alternative aquaculture systems that can utilize fish farming waste and can save land and water uses. The purpose of this study was to inform farmers about culturing Nile tilapia and water spinach with the aquaponic system. This activity was conducted for 37 days from September to November 2018, using a concrete pond, $(3 \mathrm{~m} \times 1 \mathrm{~m}, 5 \times 1 \mathrm{~m})$, with the amount of fish stocked 200 fish. The results showed that the growth of Nile tilapia was $3,31 \pm 0,86 \mathrm{~cm}$ in terms of length and $21,59 \pm 4,28 \mathrm{~g}$ in terms of weight. The specific growth rate of nile tilapia was $2,07 \%$ day $^{-1}$ with a survival rate of $95 \%$. The growth of water spinach is $47,86 \pm 2,81 \mathrm{~cm}$ and $16,85 \pm 2,47 \mathrm{~g}$.

Keywords : Tilapia, Kale plant, Aquaponic

\section{PENDAHULUAN}

Ikan nila (Oreochromis niloticus) merupakan salah satu ikan air tawar yang mendapat perhatian cukup besar dari pemerintah yang diharapkan dapat menyumbang peningkatan produksi, pun mendapat perhatian dari masyarakat dunia, yang menitik beratkan pada peningkatan gizi masyarakat di negara-negara berkembang (Khairuman dan Amri, 2005). Program minapadi turut memberikan kontribusi terhadap peningkatan produksi ikan nila nasional. Angka tahun 2017 produksi ikan nila mencapai 1,15 juta ton atau naik sebesar 3,6 persen dari tahun 2016 yang mencapai 1,14 juta ton (KKP, 2018).
Realisasi dari target peningkatan produksi, kegiatan budidaya ikan nila yang dilakukan secara intensif dengan kepadatan tinggi dan input pakan. Konsekuensi dari hal tersebut dapat menyebabkan penurunan kualitas air. Hal tersebut disebabkan oleh peningkatan produksi limbah dari sisa metabolit ikan. Hal tersebut menjadikan faktor pembatas di dalam produksi perikanan, sedangkan budidaya ikan nila, tidak terlepas dari penggunaan air media budidaya baik kuantitas maupun kualitas perairan.

Masalah lain dalam kegiatan budidaya, selain limbah adalah berkurangnya lahan kosong untuk kegiatan 
budidaya maupun sumber air yang semakin kritis, hal ini dikarenakan air merupakan faktor penting dalam menunjang aktivitas manusia, dan sebagai media untuk kegiatan bidang perikanan (Marlina dan Rakhmawati, 2016).

Keterbatasan lahan dan ketersediaan sumber air perlu dicarikan solusi agar kegiatan budidaya dapat terus berkembang. Sistem akuaponik yaitu perpaduan antara tanaman hortikultura dan pemeliharaan ikan. Akuaponik merupakan salah satu alternatif yang dapat memanfaatkan limbah budidaya ikan dan mampu menghemat penggunaan lahan dan air (Nuryadi et al., 2009).

Tanaman hortikultura berfungsi sebagai filter dengan metode resirkulasi sehingga air media sebagai limbah budidaya dapat digunakan kembali untuk proses pemeliharaan ikan. Keuntungan lain yang diperoleh dari sistem akuaponik adalah efisiensi penggunaan lahan dan air dan bisa menghasilkan keuntungan tambahan dari hasil tanaman (Marlina dan Rakhmawati, 2016; Anjani et al., 2019; Sukoco et al., 2019). Kegiatan ini menerapkan sistem akuaponik dengan menggunakan sayuran kangkung dan ikan nila. Sayuran kangkung merupakan tanaman yang bisa digunakan untuk sistem akuaponik. Nutrisi tanaman kangkung diperoleh dari penyerapan oleh akar-akar tanaman kangkung terhadap nutrisi yang ada di media pemeliharaan ikan (Perdana $e t$ al., 2015).

Tujuan penelitian ini adalah memberikan informasi kepada para pembudidaya mengenai pemeliharaan ikan nila dan tanaman kangkung dengan sistem akuaponik. Kegunaan dari kegiatan ini adalah masyarakat setempat dan para pembudidaya dapat menerapkan sistem akuaponik sehingga dapat mengoptimalkan lahan yang terbatas untuk menghasilkan ikan dan sayuran.

\section{METODOLOGI}

\section{Waktu dan Tempat}

Penelitian ini dilaksanakan pada bulan September sampai November 2018 di Desa Karang Endah, Kecamatan Gelumbang, Kabupaten Muara Enim, Sumatra Selatan. Demplot dilakukan pada satu kolam petani ikan yang bersedia menjadi percontohan bagi kelompok taninya.

\section{Materi Penelitian}

Alat yang digunakan pada kegiatan disajikan pada Tabel 1.

Tabel 1. Alat yang digunakan pada kegiatan.

\begin{tabular}{llll}
\hline No & \multicolumn{1}{c}{ Alat } & \multicolumn{1}{c}{ Spesifikasi } & \multicolumn{1}{c}{ Kegunaan } \\
\hline 1. & Kolam beton & $3 \times 1,5 \times 1 \mathrm{~m}^{3}$ & Media pemeliharaan \\
2. & Cup Air Mineral & Berdiameter $\pm 10 \mathrm{~cm}$ & Pot untuk tanaman \\
3. & pH meter & $0,1 \mathrm{ppm}$ & Alat ukur pH air \\
5 & Termometer & $0,1^{\circ} \mathrm{C}$ & Pengukur suhu \\
6 & DO meter & $0,01 \mathrm{mg} . \mathrm{L}^{-1}$ & Pengukur oksigen terlarut \\
7 & Timbangan digital & $0,1 \mathrm{gram}$ & Penimbang bobot ikan \\
8 & Penggaris & $0,1 \mathrm{~cm}$ & Pengukur panjang ikan \\
9 & Pompa & WP-105, 3000 L/jam & Penyedot air filter \\
10 & TDS meter & $0,1 \mathrm{ppm}$ & Pengukur TDS \\
11 & Botol kemasan & $1,5 \mathrm{~L}$ & Penyimpan sampel air BOD dan TDS \\
12 & Rock wool & $0,5 \mathrm{~m}$ & Media semai tanaman \\
13 & Pipa PVC & $3 \times 3 \mathrm{~cm}$ & Penyalur air resirkulasi \\
14 & Elbow & $3 \mathrm{inci}$ & Penyambung pipa \\
15 & Spektrofotometer & $3 \mathrm{inci}$ & Mengukur kandungan amonia \\
& & $0,0001 \mathrm{mg} . \mathrm{L}^{-1}$ & \\
\hline
\end{tabular}


Bahan yang digunakan pada kegiatan disajikan pada Tabel 2 .

Tabel 2. Bahan yang digunakan pada kegiatan.

\begin{tabular}{llll}
\hline No. & \multicolumn{1}{c}{ Bahan } & \multicolumn{1}{c}{ Spesifikasi } & \multicolumn{1}{c}{ Kegunaan } \\
\hline 1 & Ikan nila & Ukuran $\pm 10 \mathrm{~cm}$ & Ikan yang di pelihara \\
2 & Tanaman Kangkung & - & Biofilter dan tanaman sayur \\
3 & Pelet & $30 \%$ & Pakan ikan \\
4 & Kerikil & - & Filter dan tempat akar tanaman merambat \\
& & & Kalibrasi alat \\
5 & Akuades & & \\
\hline
\end{tabular}

\section{Rancangan Penelitian}

Kegiatan ini menggunakan metode pengambilan data eksperimen tunggal dengan perlakuan akuaponik tanaman kangkung untuk budidaya ikan nila. Parameter yang diamati meliputi parameter fisika berupa suhu, parameter kimia berupa oksigen terlarut, kebutuhan oksigen biologis, amonia, padatan total terlarut, dan parameter biologis berupa kelangsungan hidup ikan, pertumbuhan ikan dan kangkung, rasio konversi pakan.

\section{Prosedur Kerja}

Bibit kangkung berupa biji disemai terlebih dahulu menggunakan rock wool sebagai media semai. Rock wool dipotong ukuran $3 \times 3 \mathrm{~cm}$, setelah itu dibuat lubang tanam pada rock wool dan dibasahi menggunakan air. Biji kangkung direndam dalam air selama 24 jam, kemudian dimasukkan ke dalam lubang semai. Penyemaian dilakukan kurang lebih selama 7 hari sampai kangkung tumbuh. Tempat penyemaian diletakkan di bawah sinar matahari agar kangkung dapat tumbuh dengan baik.

Pemeliharaan ikan dengan sistem akuaponik dimulai dengan persiapan kolam beton berukuran $3 \times 1,5 \times 1 \mathrm{~m}$. Kolam dibersihkan terlebih dahulu sebelum digunakan. Kemudian pipa dilubangi untuk tempat meletakkan pot tanaman. Pipa PVC (Polyvinyl chloride) disambung dengan pipa PVC yang lain menggunakan elbow dan dob. Pipa PVC berfungsi untuk menghubungkan antara kolam atau wadah pemeliharaan ikan dengan media tanaman dan juga menghubungkan antara media tanam dengan kolam kembali. Pompa dipasang pada wadah pemeliharaan ikan dan selang pada pompa disambungkan pada pipa PVC. Setelah kolam atau wadah pemeliharaan ikan telah siap, maka bibit kangkung yang sudah disemai dimasukkan ke dalam gelas air mineral yang sudah diisi kerikil dan diletakkan ke dalam pipa PVC yang sudah dilubangi.

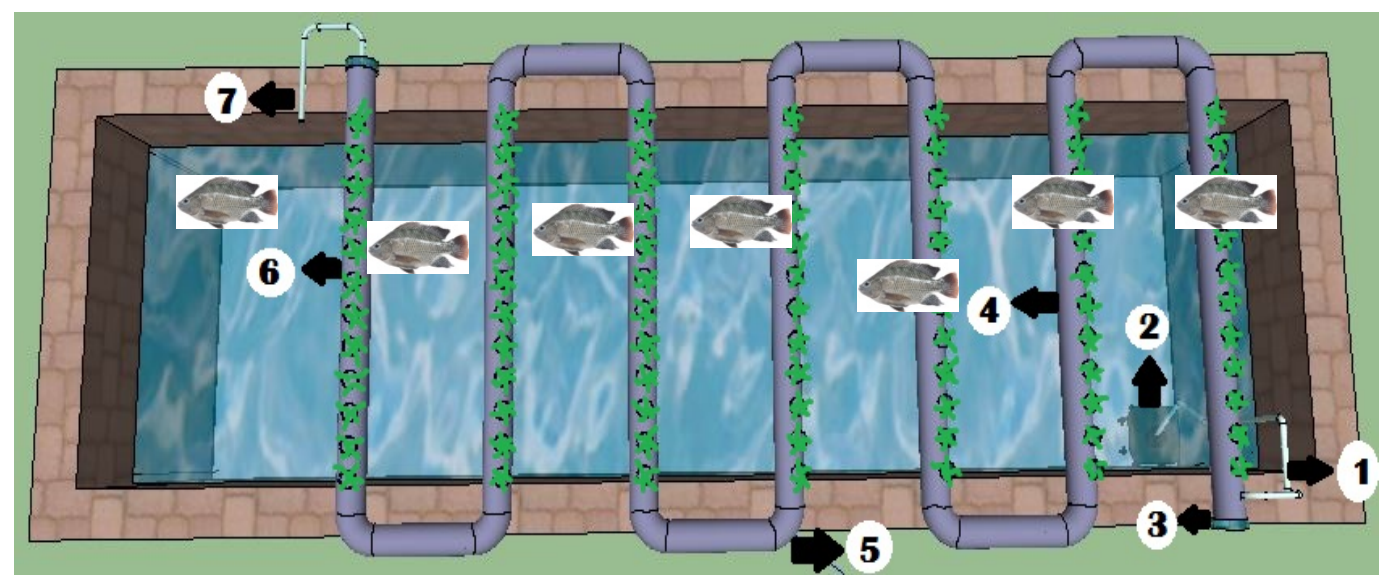

Gambar 1. Skema akuaponik. 
Keterangan:

1. Selang (Saluran air masuk)

2. Pompa

3. $D o b$

4. Pipa PVC

Sebelum ikan ditebar dalam wadah pemeliharaan, terlebih dahulu dilakukan pengukuran bobot ikan nila menggunakan timbangan analitik dan mistar untuk mengukur panjang ikan nila. Penebaran ikan nila dengan kepadatan 1 ekor per 2 liter dilakukan dengan cara diaklimatisasi terlebih dahulu agar tidak mengalami stres dan dapat menyesuaikan lingkungan di wadah pemeliharaan. Ikan dipelihara selam 37 hari dalam sistem akuaponik dengan tanaman kangkung sebagai biofilter.

Selama waktu pemeliharaan pemberian pakan ikan dilakukan dengan metode at satiation dengan periode waktu pemberian pakan dilakukan pada pukul 08.00 WIB, 12:00 WIB, dan 16.00 WIB.

\section{Parameter yang Diamati}

Parameter yang diamati selama pemeliharaan ikan nila dengan sistem akuaponik meliputi parameter fisika kimia media pemeliharaan, dan biologis ikan.

Pengukuran suhu dilakukan pada
awal pemeliharaan
pemeliharaan dan dilakukan setiap hari dengan tujuan untuk mengetahui perubahan suhu pada air setiap harinya. Pengukuran dilakukan dengan menenggelamkan bagian badan sensoris dari termometer, posisi termometer dipertahankan sampai nilai yang tertera di layar digital stabil.

Oksigen terlarut diukur dengan menggunakan DO meter. DO meter dikalibrasi menggunakan akuades yang bertujuan agar DO meter netral dari larutanlarutan yang sebelumnya sudah pernah digunakan. Pengukuran dilakukan dengan menenggelamkan bagian badan sensoris dari DO meter, posisi DO meter dipertahankan sampai nilai yang tertera di layar digital stabil.

\author{
5. Elbow \\ 6. Media dan Tanaman Kangkung \\ 7. Selang (Saluran air keluar)
}

Larutan standar dibuat dengan cara sebagai berikut: $1,9 \mathrm{~g} \mathrm{NH}_{4} \mathrm{Cl}$ diencerkan dalam $500 \mathrm{ml}$ akuades, $5 \mathrm{ml}$ dimasukkan dalam pengenceran ke-2, selanjutnya diambil $15 \mathrm{ml}$ dan dimasukkan ke dalam pengenceran ke-3. Larutan standar diambil $10 \mathrm{ml}$ dan dimasukkan ke dalam Erlenmeyer yang ditambahkan 1 tetes $\mathrm{MnSO}_{4}, 0,5 \mathrm{ml}$ chlorox dan 0,6 $\mathrm{ml}$ fenat sambil diaduk, selanjutnya larutan didiamkan sampai warna stabil.

Larutan blangko dibuat dengan cara sebagai berikut: $10 \mathrm{ml}$ akuades diambil dan dimasukkan ke dalam Erlenmeyer yang telah ditambahkan 1 tetes $\mathrm{MnSO}_{4}, 0,5 \mathrm{ml}$ chlorox dan 0,6 ml fenat sambil diaduk, selanjutnya larutan didiamkan sampai warna stabil.

Larutan sampel air sampel diambil sebanyak $20 \mathrm{ml}$ dan disaring menggunakan kertas saring sebanyak $10 \mathrm{ml}$. Selanjutnya dimasukkan ke dalam Erlenmeyer yang telah ditambahkan 1 tetes $\mathrm{MnSO}_{4}, 0,5 \mathrm{ml}$ chlorox dan $0,6 \mathrm{ml}$ fenat sambil diaduk, selanjutnya larutan didiamkan sampai warna stabil. Atur spektrofotometer pada absorbance 0,000, penghitungan sampel dan larutan standar dilakukan dengan bantuan larutan blangko pada panjang gelombang $630 \mathrm{~nm}$. Perhitungan dihitung dengan persamaan sebagai berikut:

$$
\begin{gathered}
(\mathrm{TAN}) \mathrm{mg} / \mathrm{L} \text { sebagai } \mathrm{N}=\mathrm{mg} / \mathrm{L} \mathrm{NNH} \\
=(\text { Cst } \times \text { As) } / \mathrm{As}
\end{gathered}
$$

Keterangan:

$\mathrm{C}_{\text {st }} \quad$ : Konsentrasi larutan standar $(0,3 \mathrm{mg} / \mathrm{L})$

$\mathrm{A}_{\text {st }}$ : Nilai absorbance atau nilai transmittance larutan standar

$\mathrm{A}_{\mathrm{s}} \quad$ : Nilai absorbance atau nilai transmittance air sampel

TDS (Total Dissolved Solid) diukur menggunakan TDS meter yang telah dikalibrasi. Pengukuran dilakukan dengan menenggelamkan bagian badan sensoris dari TDS meter, posisi TDS meter 
dipertahankan sampai nilai yang tertera di layar digital stabil.

BOD (Biochemical Oxygen Demand) diukur dengan cara air sampel diambil sebanyak 1-2 liter dari kolam budidaya. Air sampel dimasukkan ke dalam botol BOD gelap dan terang sampai penuh. Air dalam botol BOD terang dianalisis kadar oksigen terlarutnya dengan menggunakan DO meter ataupun dengan menggunakan metode titrasi, sedangkan air di dalam BOD gelap ditentukan dengan menggunakan DO meter ataupun titrasi. Kadar BOD ditentukan dengan rumus berikut (BSN, 2009) : [kadar\{DO(0 hari)-DO(5 hari\}]ppm

Ikan nila dan tanaman kangkung diukur bobot mutlak dengan menggunakan rumus sebagai berikut (Effendi, 2009) :

$\mathrm{W}=\mathrm{Wt}-\mathrm{Wo}$

Keterangan:

W : Pertumbuhan berat mutlak (gram)

$\mathrm{W}_{\mathrm{t}}$ : Bobot ikan pada akhir pemeliharaan (gram)

Wo : Bobot ikan pada awal pemeliharaan (gram)

Ikan nila dan tanaman kangkung diukur panjang mutlak dengan menggunakan rumus sebagai berikut (Effendi, 2009) :

$\mathrm{L}=\mathrm{Lt}-\mathrm{Lo}$

Keterangan:

L : Pertumbuhan berat mutlak (gram)

$\mathrm{L}_{\mathrm{t}} \quad$ : Bobot ikan pada akhir pemeliharaan (gram)

Lo : Bobot ikan pada awal pemeliharaan (gram)

Perhitungan laju pertumbuhan spesifik digunakan rumus yang dikemukakan oleh Hariati (1989), sebagai berikut:

$\mathrm{SGR}=\frac{\ln \mathrm{Wt}-\ln \mathrm{Wo}}{\mathrm{t}} \times 100 \%$

Keterangan:

SGR : Pertumbuhan berat mutlak (gram)

$\mathrm{W}_{\mathrm{t}}$ : Bobot ikan pada akhir pemeliharaan (gram)

Wo : Bobot ikan pada awal pemeliharaan (gram)

$\mathrm{t}$ : Lama waktu pemeliharaan (hari)
Berdasarkan data jumlah ikan hidup pada akhir pemeliharaan dan jumlah ikan yang ditebar pada awal pemeliharaan, dapat diketahui tingkat kelangsungan hidup menggunakan rumus sebagai berikut (Effendi, 2009):

$\mathrm{SR}=\frac{\mathrm{Nt}}{\mathrm{No}} \times 100 \%$

Keterangan:

SR : Kelangsungan hidup (\%)

$\mathrm{N}_{\mathrm{t}}$ : Jumlah ikan pada akhir pemeliharaan (ekor)

No : Jumlah ikan pada awal pemeliharaan (ekor)

Perhitungan konversi pakan dilakukan dengan menggunakan rumus Tacon (1987), sebagai berikut:

$$
\mathrm{FCR}=\frac{\mathrm{F}}{((\mathrm{Wt}+\mathrm{D})-\mathrm{Wo})}
$$

Keterangan:

FCR : Rasio konversi pakan

$\mathrm{W}_{\mathrm{t}}$ : Bobot ikan akhir (gram)

Wo : Bobot ikan awal (gram)

F : Pakan yang diberikan (gram)

D : Bobot ikan mati selama pemeliharaan (gram)

\section{Analisis Data}

Pengumpulan data pertumbuhan (Panjang dan Bobot) serta kelangsungan hidup ikan, data FCR dari awal hingga akhir pemeliharaan dianalisis secara deskriptif. Data kualitas air diukur pada awal, minggu ke-1,2,3 dan $4(\mathrm{pH})$, setiap hari (suhu), serta pada awal dan akhir (DO, amonia, TDS, dan BOD) dan dianalisis secara deskriptif dibandingkan dengan data literatur sebelumnya.

\section{HASIL DAN PEMBAHASAN}

\section{Pertumbuhan Ikan dan Tanaman Kangkung}

Data hasil pertumbuhan mutlak ikan nila selama pemeliharaan dengan menggunakan sistem akuaponik disajikan pada Tabel 3.

Tabel 3. Pertumbuhan mutlak ikan nila.

\begin{tabular}{lccc}
\hline Parameter & Awal & Akhir & Hasil Pertumbuhan \\
\hline Panjang $(\mathrm{cm})$ & $10,22 \pm 0,48$ & $13,53 \pm 0,88$ & $3,31 \pm 0,68$ \\
Bobot $(\mathrm{g})$ & $19,33 \pm 1,20$ & $40,92 \pm 3,08$ & $21,59 \pm 4,28$ \\
\hline
\end{tabular}


Pertumbuhan mutlak ikan nila pada sistem akuaponik selama 37 hari pemeliharaan mencapai rata-rata pertambahan panjang $3,31 \mathrm{~cm}$ dan pertambahan bobot 21,59 gram.
Data hasil pertumbuhan mutlak tanaman kangkung selama pemeliharaan dengan menggunakan sistem akuaponik disajikan pada Tabel 4.

Tabel 4. Pertumbuhan mutlak tanaman kangkung.

\begin{tabular}{lccc}
\hline Parameter & Awal & Akhir & Hasil Pertumbuhan \\
\hline Panjang (cm) & $9,14 \pm 1,04$ & $57 \pm 2,75$ & $47,86 \pm 2,81$ \\
Bobot $(\mathrm{g})$ & $0,23 \pm 0,03$ & $17,08 \pm 2,73$ & $16,85 \pm 2,74$ \\
\hline
\end{tabular}

Pertumbuhan yang diperoleh selama pemeliharaan ikan nila menggunakan sistem akuaponik menunjukkan bobot pada awal penebaran sebesar $19,33 \pm 1,20$ gram dan akhir 40,92 $\pm 3,08$ gram dengan panjang ikan pada awal penebaran 10,22 $\pm 0,48 \mathrm{~cm}$ dan akhir 13,53 $\pm 0,88 \mathrm{~cm}$. Pertambahan bobot ikan nila adalah sebesar 21,59 $\pm 4,28$ gram dan pertambahan panjang sebesar $3,21 \pm 0,68 \mathrm{~cm}$, dengan laju pertumbuhan spesifik ikan nila dalam sistem akuaponik sebesar 2,07\% .hari $^{-1}$. Nilai pertumbuhan tersebut lebih rendah dari pertumbuhan ikan nila pada penelitian Mulqan et al. (2017) yang menyatakan bahwa laju pertumbuhan spesifik ikan nila dalam sistem akuaponik menggunakan tanaman kangkung sebesar 2,36\% .hari $^{-1}$.

Pertumbuhan ikan selama pemeliharaan dipengaruhi oleh kadar protein pakan yang diberikan. Protein pakan yang diberikan sekitar $30 \%$. Selain itu pertumbuhan ikan nila juga didukung oleh pakan alami yang tersedia di kolam pemeliharaan. Kolam pemeliharaan yang digunakan dalam kegiatan ini berupa kolam beton yang terkena cahaya matahari secara langsung, sehingga memicu pertumbuhan pakan alami, yang dapat dilihat dari perubahan warna air kolam menjadi hijau.

Ikan nila sendiri tergolong ikan herbivora cenderung karnivora yang dapat memakan fitoplankton, zooplankton dan serasah yang ada di kolam (Setia et al., 2010), sehingga plankton dan serasah dapat menjadi pakan tambahan yang mendukung pertumbuhan ikan nila selama pemeliharaan.
Pertumbuhan bobot tanaman kangkung selama pemeliharaan dalam sistem akuaponik yaitu dengan bobot tanaman kangkung bobot pada awal pemeliharaan sebesar $0,23 \pm 0,03$ gram dan akhir $17,08 \pm 2,73$ gram dengan panjang tanaman kangkung pada awal pemeliharaan sebesar 9,14 $\pm 01,04 \mathrm{~cm}$ dan akhir pemeliharaan sebesar $57 \pm 2,75 \mathrm{~cm}$. Laju pertumbuhan spesifik tanaman kangkung sebesar 11,95\%.hari ${ }^{-1}$. Menurut Effendi (2015), tanaman kangkung dapat memanfaatkan limbah budidaya ikan untuk pertumbuhan. Laju pertumbuhan spesifik kangkung (Ipomoea aquatica) dipengaruhi oleh nutrien di air. Pertumbuhan tanaman kangkung dipengaruhi oleh keadaan air kolam selama pemeliharaan, dimana tanaman kangkung memanfaatkan nutrisi yang tidak digunakan oleh ikan seperti sisa metabolik ikan ataupun pakan yang tidak dimakan oleh ikan.

Air yang terdapat feses ataupun sisa pakan yang tidak termakan dialirkan menggunakan pompa melalui pipa PVC sebagai tempat tumbuhnya tanaman kangkung dengan sistem resirkulasi. Hal ini diharapkan dapat meneuralgie cemaran akibat feses ataupun sisa pakan yang ada di air kolam pemeliharaan ikan nila.

\section{Kelangsungan Hidup}

Tingkat kelangsungan hidup ikan nila pada pemeliharaan dengan sistem akuaponik mencapai 95\%, dimana jumlah ikan yang ditebar pada awal pemeliharaan sebanyak 200 ekor, dan pada akhir pemeliharaan jumlah ikan yang tersisa yaitu 190 ekor. Kematian ikan nila selama 
pemeliharaan terjadi pada awal-awal pemeliharaan.

Ikan nila mengalami stres saat pemindahan dari lingkungan lama ke lingkungan baru merupakan salah satu penyebab kematian ikan. Kepadatan tebar ikan 1 ekor per 2 Liter (atau setara dengan 0,5 ekor per liter) masih layak untuk sistem akuaponik. Menurut Nugroho et al. (2012), pada sistem akuaponik, faktor padat tebar tidak berpengaruh terhadap kelangsungan hidup benih ikan nila. Kepadatan 200, 400 dan 600 ekor yang diteliti dengan ukuran kolam sebesar $2 \mathrm{~m}^{2}$ (setara dengan 0,$2 ; 0,4$; 0,6 ekor per liter) masih layak untuk dikembangkan dalam pendederan ikan nila sistem akuaponik.

\section{Konversi Pakan}

Berdasarkan hasil kegiatan yang dilakukan didapat konversi pakan ikan nila yang dipelihara selama 37 hari adalah 1,26 yang artinya untuk setiap pemberian pakan seberat $1,26 \mathrm{~kg}$ dapat menambah bobot ikan $1 \mathrm{~kg}$. Pakan yang diberikan terhadap ikan nila selama pemeliharaan dengan sistem akuaponik yaitu pelet komersial dengan frekuensi pemberian pakan tiga kali sehari.

Pemberian pakan diberikan secara at satiation. Ikan terkadang tidak memakan pakan yang diberikan karena faktor lingkungan yang fluktuatif seperti suhu yang disebabkan oleh perubahan cuaca. Konversi pakan selama pemeliharaan ikan nila dengan sistem akuaponik sebesar 1,26. Nilai ini memiliki arti bahwa untuk menghasilkan pertambahan bobot $1 \mathrm{~kg}$ ikan nila membutuhkan pakan sebanyak $1,26 \mathrm{~kg}$.

\section{Kualitas Air}

Data hasil kualitas air selama pemeliharaan dengan menggunakan sistem akuaponik disajikan pada Tabel 5. Kualitas air selama pemeliharaan ikan nila menunjukkan bahwa nilai kisaran suhu, $\mathrm{pH}$, oksigen terlarut, total padatan terlarut, kebutuhan oksigen biokimia dan konsentrasi amonia semua masih dalam kisaran standar budidaya ikan.

Tabel 5. Kualitas air selama pemeliharaan ikan nila dengan sistem akuaponik.

\begin{tabular}{|c|c|c|c|c|}
\hline No & Parameter & Satuan & Nilai & Standar \\
\hline 1 & Suhu & ${ }^{\circ} \mathrm{C}$ & $\begin{array}{c}29,4-32 \text { (nilai rata- } \\
\text { rata } \pm \text { SD) }\end{array}$ & $25-32^{\mathrm{a}}$ \\
\hline 2 & $\mathrm{pH}$ & - & $6,54-8,2$ & $6-8,5^{b}$ \\
\hline 3 & DO & mg. $\mathrm{L}^{-1}$ & $3,6-4,8$ & $\geq 3^{\mathrm{a}}$ \\
\hline 4 & TDS & $\mathrm{mg} . \mathrm{L}^{-1}$ & $11-135$ & $1000^{c}$ \\
\hline 5 & BOD & mg.L. ${ }^{-1}$ & $1,1-2,0$ & $<3^{d}$ \\
\hline 6 & Amonia & mg. $\mathrm{L}^{-1}$ & $0,0080-0,0095$ & $<0,02^{\mathrm{a}}$ \\
\hline
\end{tabular}

Keterangan : a. SNI:7550-2009; b. Kordi, (2010); c. PP no 82 tahun 2001 (kelas II); d. Saptarini (2010)

Kisaran suhu selama pemeliharaan ikan nila dalam media sistem akuaponik berkisar antara 29-32 ${ }^{\circ} \mathrm{C}$. Kisaran suhu tersebut dikatakan masih optimal bagi laju pertumbuhan ikan nila untuk tumbuh. Hal ini sesuai dengan pernyataan Khairuman dan Amri (2013) yang menyatakan bahwa ikan nila dapat tumbuh secara normal pada kisaran suhu $14-38{ }^{\circ} \mathrm{C}$. Kisaran suhu yang cenderung berubah disebabkan oleh adanya perubahan cuaca selama pemeliharaan ikan nila dengan sistem akuaponik.
Kisaran $\mathrm{pH}$ yang diperoleh dari kolam pemeliharaan ikan nila dengan sistem akuaponik yaitu berkisar antara 6,54-8,20. Nilai pH air tersebut masih cocok untuk digunakan dalam pemeliharaan ikan nila. Kordi (2010) menyatakan bahwa $\mathrm{pH}$ yang cocok untuk pemeliharaan ikan nila adalah 6-8,5, namun pertumbuhan optimalnya terjadi pada $\mathrm{pH} 7-8$. Nilai $\mathrm{pH}$ yang masih ditoleransi oleh ikan nila antara 5-11.

Kandungan oksigen terlarut pada pemeliharaan ikan dengan sistem akuaponik tergolong tinggi untuk 
pertumbuhan optimal ikan. Kisaran oksigen terlarut selama pemeliharaan pada kegiatan ini berkisar antara 3,6-4,8 mg. $\mathrm{L}^{-1}$. Kisaran tersebut sudah memenuhi kebutuhan oksigen untuk pemeliharaan ikan nila. Kordi (2010) menyatakan bahwa pertumbuhan optimal ikan nila membutuhkan perairan dengan kandungan oksigen minimal $3 \mathrm{mg} . \mathrm{L}^{-1}$.

Konsentrasi Total Disolved Solid (TDS) pada pemeliharaan ikan nila dengan sistem akuaponik memiliki konsentrasi 11 mg.L. ${ }^{-1}$ - 135 mg.L - $^{-1}$, yang menunjukkan baik untuk budidaya ikan nila dengan sistem akuaponik. Berdasarkan standar baku mutu air PP No 82 tahun 2001 (kelas II), kisaran TDS untuk kegiatan budidaya ikan yaitu $1000 \mathrm{mg} . \mathrm{L}^{-1}$, yang artinya semakin kecil konsentrasi yang berada di perairan tersebut semakin baik juga untuk pemeliharaan ikan.

Kandungan BOD media pemeliharaan dengan sistem akuaponik dapat dikategorikan baik, yaitu berada di kisaran 1,1 - 2,0 ppm. Saptarini (2010) menyatakan bahwa kolam akuaponik memiliki nilai $\mathrm{BOD}<3 \mathrm{mg} . \mathrm{L}^{-1}$ yang menunjukkan bahwa air di kolam akuaponik tidak tercemar, nilai BOD $>5$ mg. $\mathrm{L}^{-1}$, yang menunjukkan air di tercemar sedang.

Menurut Effendi (2003), amonia yang terukur di perairan berupa amonia total $\left(\mathrm{NH}_{3}\right.$ dan $\left.\mathrm{NH}_{4}^{-}\right)$. Amonia bebas tidak dapat terionisasi, sedangkan amonium $\left(\mathrm{NH}_{4}{ }^{-}\right)$ dapat terionisasi. Persentase amonia bebas meningkat dengan meningkatnya nilai $\mathrm{pH}$ dan suhu perairan. Pada $\mathrm{pH} 7$ atau kurang, sebagian besar amonia akan mengalami ionisasi. Sebaliknya pada $\mathrm{pH}$ lebih besar dari 7 amonia tidak terionisasi. Kandungan amonia total selama pemeliharaan dalam sistem akuaponik berkisar antara 0,16 $0,19 \mathrm{mg} \cdot \mathrm{L}^{-1}$. $\mathrm{pH}$ pada pemeliharaan sebesar 8,2 , sehingga dari kandungan total amonia yang terukur diduga $95 \%$ amonia terionisasi. Amonia bebas yang tidak terionisasi sebesar 0,008 mg.L-1 - 0,0095 mg. $L^{-1}$.
Berdasarkan

SNI:7550-2009, produksi ikan nila kelas pembesaran di kolam air tenang, amonia dalam proses produksi ikan nila $<0,02 \mathrm{mg} \cdot \mathrm{L}^{-1}$. Hasil penelitian Marlina dan Rakhmawati (2016) menunjukkan bahwa kandungan amonia $\left(\mathrm{NH}_{3}\right)$ dalam media akuaponik lebih rendah dibandingkan media non-akuaponik. Media akuaponik memiliki kandungan amonia $\left(\mathrm{NH}_{3}\right)$ sebesar 0,01695 mg.L ${ }^{-1}$. Sedangkan pada media non-akuaponik kandungan amonia $\left(\mathrm{NH}_{3}\right)$ sebesar 0,0610 mg. $L^{-1}$.

\section{KESIMPULAN DAN SARAN Kesimpulan}

Pemeliharaan ikan nila dengan sistem akuaponik menggunakan tanaman kangkung menunjukkan pertumbuhan yang cukup baik, laju pertumbuhan spesifik sebesar 2,07\%.hari ${ }^{-1}$ dengan tingkat kelangsungan hidup ikan sebesar $95 \%$. Di samping itu, tanaman kangkung mengalami pertumbuhan panjang sebesar $47,86 \pm 2,81$

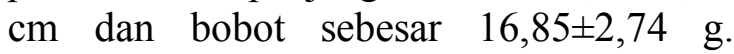
Kualitas air selama pemeliharaan dengan sistem akuaponik didapatkan suhu yang berkisar antara $29,4-32{ }^{\circ} \mathrm{C}, \mathrm{pH}$ berkisar antara 6,54-8,2, DO berkisar antara 3,6-4,8, TDS berkisar antara 11-135 mg.L $\mathrm{L}^{-1}$, BOD berkisar antara 1,1-2,0 mg.L $\mathrm{L}^{-1}$ dan amonia berkisar antara 0,0080-0,0095 mg. $\mathrm{L}^{-1}$.

\section{Saran}

Desain akuaponik dengan aliran air yang diberi filter (seperti filter fisik, kimia, dan mikrobiologis) sebelum dialirkan ke media tanaman akan lebih baik dibandingkan dengan aliran air yang langsung dari kolam pemeliharaan ke media tanam.

\section{DAFTAR PUSTAKA}

Anjani, P.T., Kusdarwati, R. and Sudarno, S., 2019. Pengaruh teknologi akuaponik dengan media tanam selada (lactuca sativa) yang berbeda terhadap pertumbuhan belut (Monopterus albus). Journal of 
Aquaculture and Fish Health, 6(2), pp.67-73.

Badan Standarisasi Nasional. BSN, 2009. SNI Air dan Air Limbah Bagian 72: Cara Uji Kebutuhan Oksigen Biokimia (Biochemical Oxygen Demand/BOD). SNI, 6989, Jakarta.

Badan Standarisasi Nasional. BSN, 2009. SNI produksi benih ikan nila (Oreochromis niloticus) kelas pembesaran di kolam air tenang SNI 7550:2009, Jakarta.

Effendi, H., 2003. Telaah Kualitas Air, Bagi Pengelolaan Sumber Daya dan Lingkungan Perairan. Yogyakarta, Kanisius.

Effendi, I., 2009. Pengantar Akuakultur. 188 hal. Jakarta, Penebar Swadaya.

Hariati, A.M., 1989. Makanan Ikan. Diktat Kuliah Universitas Brawijaya. Malang, 155.

Kementerian Kelautan dan Perikanan. KKP, 2018. Kelautan dan Perikanan Dalam Angka (KPDA) 2018.

Khairuman, A. dan Amri, K., 2005. Budi Daya Ikan Nila Secara Intensif. Jakarta, AgroMedia.

Khairuman, H. dan Amri, K., 2013. Budidaya Ikan Nila. Jakarta, AgroMedia.

Kordi, K.M.G.H., 2010. Budidaya Ikan Nila di Kolam Terpal. Yogyakarta, Lily Publisher.

Marlina, E. dan Rakhmawati, R., 2016. Kajian Kandungan Ammonia pada Budidaya Ikan Nila (Oreochromis niloticus) menggunakan teknologi akuaponik tanaman tomat (Solanum lycopersicum). Prosiding Seminar Nasional Tahunan Ke-V Hasil-Hasil Penelitian Perikanan dan Kelautan.

Mulqan, M., Rahimi, E., Afdhal, S. dan Dewiyanti, I., 2017. Pertumbuhan dan Kelangsungan Hidup Benih Ikan Nila Gesit (Oreochromis niloticus) Pada Sistem Akuaponik Dengan Jenis Tanaman Yang Berbeda. Jurnal Ilmiah Mahasiswa Kelautan Perikanan Unsyiah, 2(1). 183-193.
Nugroho, R.A., Pambudi, L.T., Chilmawati, D., dan Haditomo, A.H.C., 2012. Aplikasi teknologi akuaponik pada budidaya ikan air tawar untuk optimalisasi kapasitas produksi. Saintek Perikanan: Indonesian Journal of Fisheries Science and Technology, 8(1), pp.46-51.

Nuryadi, N., Sutrisno, S. dan Puspaningsih, D., 2009. Fitoremediasi kolam pemeliharaan ikan dengan memanfaatkan sayuran. Media Akuakultur. 4(1), pp. 50-53.

Peraturan Pemerintah No. 82. Tahun 2001. Pengelolaan Kualitas Air dan Pengendalian Pencemaran Air. Jakarta, Kementrian Lingkungan Hidup.

Perdana, T.R., Raza'i, T.S. dan Zulfikar, A., 2015. Tingkat Penyerapan Tanaman Kangkung (Ipomoea reptans) Dengan Luasan Wadah Tanam Sistem Akuaponik Yang Berbeda Terhadap Kandungan Amonia $\left(\mathrm{NH}_{3}\right)$ Pada Limbah Budidaya Lele. Riau, Manajemen Sumberdaya Perairan, FIKP UMRAH.

Saptarini, P., 2010. Efektivitas Teknologi Akuaponik Dengan Kangkung Darat (Ipomea Reptans) Terhadap Penurunan Amonia Pada Pembesaran Ikan Mas. Skripsi. Departemen Manajemen Sumberdaya Perairan, Fakultas Perikanan dan Ilmu Kelautan, Institut Pertanian Bogor. Bogor.

Setia, Y., Octorina, dan Yulfiperius, P., 2010. Kebiasaan makanan ikan nila (Oreochromis niloticus) di danau bekas galian pasir Gekbrong Cianjur - Jawa Barat. Jurnal Agroqua 9(1).

Sukoco, F.A., Rahardja, B.S. dan Manan, A., 2019. Pengaruh pemberian probiotik berbeda dalam sistem akuaponik terhadap FCR (feed convertion ratio) dan biomassa ikan lele (Clarias sp.). Journal of Aquaculture and Fish Health, 6(1), pp.24-31. 
Journal of Aquaculture and Fish Health Vol. 8 No.3 (2019)

Tacon, A.G.J., 1987. The nutrition and feeding of farmed fish and shrimp: A training manual. Brasilia, FAO. 